\title{
Cancer stem cells, the ultimate targets in cancer therapy
}

This article was published in the following Dove Press journal: OncoTargets and Therapy

\author{
Ahmed Shabbir ${ }^{1}$ \\ Tuba Esfandyari ${ }^{2}$ \\ Faris Farassati ${ }^{1,3,4}$ \\ 'Midwest Biomedical Research \\ Foundation, Kansas City Veterans \\ Affairs Medical Center, ${ }^{2}$ Department \\ of Medicine, School of Medicine, The \\ University of Kansas, ${ }^{3}$ Saint Luke's \\ Cancer Institute, ${ }^{4}$ Saint Luke's Marion \\ Bloch Neuroscience Institute, Saint \\ Luke's Health System, Kansas City, \\ MO, USA
}

The concept of cancer stem cells (CSCs) is currently of significant interest due to its important implications in our understanding of the tumor biology as well as development of novel cancer therapeutics. Tumors, in resemblance to normal organs, contain pluripotential cells that can generate their own kind as well as cells that can further differentiate. CSCs are thought to be highly resistant to the cytotoxic effects of conventional cancer therapy regimens, ${ }^{1}$ which leads to the rise of a refractory status in tumors. ${ }^{1,2}$ Therefore, CSCs can be considered as the main drivers of tumor integrity and function. This resembles the role of normal stem cells in tissue and organ development. Therapeutic assaults that eliminate differentiated cancer cells while leaving CSCs, therefore, are doomed to fail due to the resistance of CSCs and their ability to repopulate the tumor. ${ }^{3}$ This phenomenon is indeed observed in the clinic routinely. Clinical response to a chemotherapy regimen is reduced over time as the tumor enters a refractory stage induced by enrichment of CSCs in the tumor cell population. This is even observed in cells cultured from a patient at early stage of the disease, such as in colorectal cancer (SW480, ATCC CCL-228), and recurrence of the malignancy results in a wide-spread metastasis (SW620, ATCC CCL-227). The SW260 shows a significantly higher percentage of cells positive for CD133, a marker for CSCs (data from our team). Methods for the detection of CSCs include surface markers such as CD24, CD34, CD44, CD44, CD90, CD133, ABCB5, and EpCAM that have been shown to indicate CSC subpopulations in a range of malignancies. ${ }^{4}$ Additionally, functional tests, such as detection of side population phenotype by Hoechst 33342 exclusion, the ability to grow as floating spheres in serum-free medium, and ALDH activity, have also been utilized to detect and isolate CSCs.

From the therapeutic perspective, two main strategies have been claimed so far for targeting CSCs. The first strategy is based on understanding the cell signaling characteristics of CSCs. Essentially, certain pro-oncogenic cell signaling pathways are found to be overactive in CSCs at levels higher than differentiated cancer cells or nonmalignant cells. Overactivation of these pathways contribute to phenotypic features of CSCs such as resistance to apoptosis and enhanced invasiveness. Examples of these pathways include the JAK/STAT, Wnt/ $\beta$-catenin, Hedgehog, Notch, and TGF- $\beta$ pathways. ${ }^{5,6}$ RalA signaling pathways has been shown by our group to be overactivated in a number of human malignancies such as liver, lung, medulloblastoma, malignant peripheral nerve sheath tumors, and ovarian cancer. ${ }^{7-12}$ According to our data, while the levels of RalA expression are comparable in CSCs and differentiated cancer cells, RalAGTP (the active form of RalA) is at higher levels in CSCs. Overall, none of the aforementioned cell signaling pathways are specific for CSCs; therefore,
Correspondence: Faris Farassati Kansas City Veterans Affairs Medical Center, 480I E Linwood Boulevard, Kansas City, MO 64I28, USA

Email ffarassati@gmail.com $\mathrm{BY}$
hereby accept the Terms. Non-commercial uses of the work are permitted without any further permission from Dove Medical Press Limited, provided the work is properly attributed. For permission hereby accept the Terms. Non-commercial uses of the work are permitted without any further permission from Dove Medic
for commercial use of this work, please see paragraphs 4.2 and 5 of our Terms (https://www.dovepress.com/terms.php). 
strategies based on their inhibition might influence other cells. A series of other targets with preferential expression in CSCs include surface markers (such as CD44, CD90, CD33, and CD133), ${ }^{13,14}$ multidrug resistance pump $\mathrm{ABC}^{15}$ and markers of microenvironment (such as CXCL12/CXCR4 and VEGF/VEGFR). ${ }^{16}$ The second strategy is based on the use of oncolytic viruses. Oncolytic viruses are a promising class of replication competent viruses that in many cases are advancing through clinical trials, with one member already approved by the US Food and Drug Administration for the treatment of melanoma. ${ }^{17-19}$ A number of these viruses have been claimed to destroy CSCs. Our team is focused on rational design and evaluation of mutated versions of herpes simplex-1 that are capable of targeting CSCs specifically. Our observations in this field show that targeting this minority population can effectively inhibit tumor cell growth in vitro and cause significant regression in established heterotopic and orthotopic tumors in animal models. Further research in targeting CSCs can offer highly efficient cancer remedies with minimal side effects.

\section{Disclosure}

The authors report no conflicts of interest in this work.

\section{References}

1. Polyak K, Hahn WC. Roots and stems: stem cells in cancer. Nat Med. 2006;12:296-300.

2. Aguirre-Ghiso JA. Models, mechanisms and clinical evidence for cancer dormancy. Nat Rev Cancer. 2007;7:834-846.

3. Fujiki H, Sueoka E, Rawangkan A, Suganuma M. Human cancer stem cells are a target for cancer prevention using (-)-epigallocatechin gallate. J Cancer Res Clin Oncol. Epub 2017 Sep 23.
4. Aponte PM, Caicedo A. Stemness in cancer: stem cells, cancer stem cells, and their microenvironment. Stem Cells Int. 2017;2017: 5619472.

5. Takebe N, Miele L, Harris PJ, et al. Targeting Notch, Hedgehog, and Wnt pathways in cancer stem cells: clinical update. Nat Rev Clin Oncol. 2015;12:445-464.

6. Jung HJ. Chemical proteomic approaches targeting cancer stem cells: a review of current literature. Cancer Genomics Proteomics. 2017;14: 315-327.

7. Ginn KF, Fangman B, Terai K, et al. RalA is overactivated in medulloblastoma. J Neurooncol. 2016;130:99-110.

8. Wang K, Terai K, Peng W, et al. The role of RalA in biology and therapy of ovarian cancer. Oncotarget. 2013;5:1-14.

9. Male H, Patel V, Jacob MA, et al. Inhibition of RalA signaling pathway in treatment of non-small cell lung cancer. Lung Cancer. 2012; 77:252-259.

10. Ezzeldin M, Borrego-Diaz E, Taha M, et al. RalA signaling pathway as a therapeutic target in hepatocellular carcinoma (HCC). Mol Oncol. 2014;8: 1043-1053.

11. Borrego-Diaz E, Terai K, Lialyte K, et al. Overactivation of Ras signaling pathway in CD133+ MPNST cells. J Neurooncol. 2012;108: 423-434.

12. Bodempudi V, Yamoutpoor F, Pan W, et al. Ral overactivation in malignant peripheral nerve sheath tumors. Mol Cell Biol. 2009;29:3964-3974.

13. Mallard BW, Tiralongo J. Cancer stem cell marker glycosylation: nature, function and significance. Glycoconj J. 2017;34:441-452.

14. Jang JW, Song Y, Kim SH, Kim J, Seo HR. Potential mechanisms of CD133 in cancer stem cells. Life Sci. 2017;184:25-29.

15. Ding XW, Wu JH, Jiang CP. ABCG2: a potential marker of stem cells and novel target in stem cell and cancer therapy. Life Sci. 2010;86: 631-637.

16. Wang X, Cao Y, Zhang S, et al. Stem cell autocrine CXCL12/CXCR4 stimulates invasion and metastasis of esophageal cancer. Oncotarget. 2017;8:36149-36160.

17. Fukuhara H, Ino Y, Todo T. Oncolytic virus therapy: a new era of cancer treatment at dawn. Cancer Sci. 2016;107:1373-1379.

18. Lawler SE, Speranza MC, Cho CF, Chiocca EA. Oncolytic viruses in cancer treatment: a review. JAMA Oncol. 2017;3:841-849.

19. Borrego-Diaz E, Mathew R, Hawkinson D, et al. Pro-oncogenic cell signaling machinery as a target for oncolytic viruses. Curr Pharm Biotechnol. 2012;13:1742-1749.

Dove Medical Press encourages responsible, free and frank academic debate. The content of the OncoTargets and Therapy 'Editorial' section does not necessarily represent the views of Dove Medical Press, its officers, agents, employees, related entities or the OncoTargets and Therapy editors. While all reasonable steps have been taken to confirm the content of each Editorial, Dove Medical Press accepts no liability in respect of the content of any Editorial, nor is it responsible for the content and accuracy of any Editorial.

OncoTargets and Therapy

\section{Publish your work in this journal}

OncoTargets and Therapy is an international, peer-reviewed, open access journal focusing on the pathological basis of all cancers, potential targets for therapy and treatment protocols employed to improve the management of cancer patients. The journal also focuses on the impact of management programs and new therapeutic agents and protocols on

\section{Dovepress}

patient perspectives such as quality of life, adherence and satisfaction. The manuscript management system is completely online and includes a very quick and fair peer-review system, which is all easy to use. Visit http://www.dovepress.com/testimonials.php to read real quotes from published authors. 